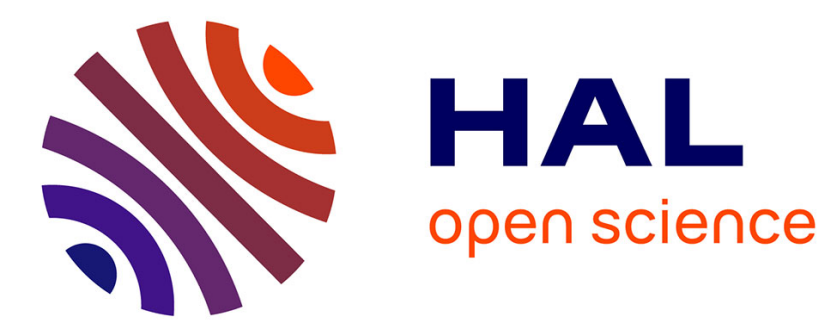

\title{
ON THE SUPPOSED NEO-STRUCTURALISM OF HYPERTEXT
}

\author{
Jean-Gabriel Ganascia
}

\section{To cite this version:}

Jean-Gabriel Ganascia. ON THE SUPPOSED NEO-STRUCTURALISM OF HYPERTEXT: ORIGINS OF HYPERTEXT. Diogenes (Engl. ed.), 2002, 49 (196), pp.8-19. 10.1177/039219210204919602 . hal-01287199

\section{HAL Id: hal-01287199 \\ https://hal.science/hal-01287199}

Submitted on 12 Mar 2016

HAL is a multi-disciplinary open access archive for the deposit and dissemination of scientific research documents, whether they are published or not. The documents may come from teaching and research institutions in France or abroad, or from public or private research centers.
L'archive ouverte pluridisciplinaire HAL, est destinée au dépôt et à la diffusion de documents scientifiques de niveau recherche, publiés ou non, émanant des établissements d'enseignement et de recherche français ou étrangers, des laboratoires publics ou privés. 
ON THE SUPPOSED NEO-STRUCTURALISM OF HYPERTEXT

by

JEAN-GABRIEL GANASCIA

\section{ORIGINS OF HYPERTEXT}

\section{A technique widely used today}

Hypertext encompasses a particular aspect of the virtual book that is playing an increasingly important part with the expansion of the Internet and the web. The success of HTML (HyperText Markup Language) - attests to its dynamism. Nowadays it seems so natural and so usual that we manipulate it with ease and we discover its ancestors among medieval cabalists or among other commentators of sacred texts. Every indexation, every note and every comment suggest a potential rudimentary hypertext. However, before its expansion over the entire planet, with the network of worldwide telecommunication, before being programmed on to every PC, hypertext took form in the minds of a few learned visionaries. We will refer to two of them.

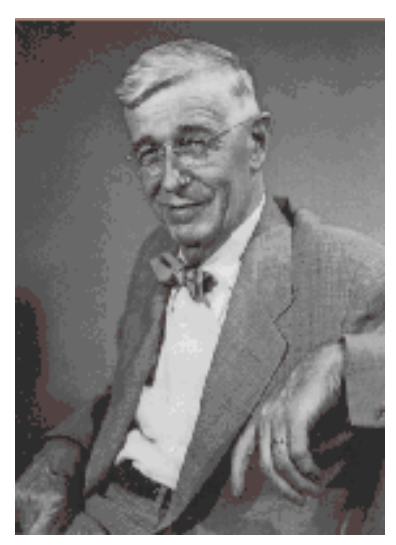




\section{Memex}

The first is Vannevar Bush, whose photograph shows him as a likeable and shrewd man in his sixties, a wonderful grandfather such as we would all like to have had! He was an outstanding physicist, notable for the quality of his work, and who, during the Second World War, was head of the United States Office for Scientific Research and Development. As director of that body, he co-ordinated the work of more than six thousand researchers who in their turn directed the war effort of American and allied scientists.

Towards the end of the war, Vannevar Bush wondered how to convert the scientists' efforts to peaceful purposes. Physicists had achieved mastery of the material world. Much knowledge had been built up during the preceding years, but at the same time people were specialising more and more with, in consequence, a much narrower outlook. What was needed then was to take advantage of all existing technical knowledge to conquer the world of the mind. In July 1945, Bush published an article entitled "As We May Think", in which he explained how the new process of dry photography would soon be recording scientific thought, so making it easier to access. According to him, new ways of thinking would result from the use of these mechanisms, which would constitute MEmory EXtensions, or, abbreviated, MEMEX.

According to Vannevar Bush, microfilm techniques would soon allow for very high density storage of information to the point where the entire Encyclopaedia Britannica would be held in a space smaller than a box of matches and that a library of a million books would be compressed to take up only one corner of a desk. Once stored, this information would become accessible by means of a few key words just as millions of telephone subscribers are by a few numbers. Moreover, we could visualize the data stored on microfilm by simply projecting them on to frosted glass. At the heart of this external memory, MEMEX as Bush called it, is a mechanism for selecting documents by association, much as our own memory would do, and not alphabetically like a rudimentary automaton. As documents are consulted they can be added to at leisure with reading notes and personal comments which remain attached to texts or passages of text, but which can also be accessed directly, and independently of the text, like filing cards. In addition, the reader can set up links between documents, which will be stored on paths - Vannevar Bush used the word 'trail', - and which will subsequently set up new connections between the various texts. 
Once selected, most of the documents contained in this external memory system will appear on a screen unless they are to be reproduced in the form of sound, either words or music. All modes of communication are envisaged and, in concluding his article, Bush

envisages even direct electrical connections with the brain by means of electrodes. Transformed into prototype Cyborgs, we would connect ourselves up directly to MEMEX without the need to read, watch or listen.

What is there to be added to this rapidly sketched picture of the grandfather of multimedia, Vannevar Bush? Nothing, except a small detail unconnected with our discussion. As co-ordinator of the Office of Research and Development during the Second World War, Vannevar Bush was responsible for the manufacture of the atomic bomb. Therefore, to paraphrase the logicians, who assert so frequently that "the morning and evening stars are the same", we could point out, without any deeper intention, that "the grandfather of the Internet was also the father of the atomic bomb". I apologise to the reader for this digression that has nothing to do with the subject of this article.

\section{Xanadu}

The second visionary, Theodor Holm Nelson, began his career by studying philosophy. He describes how he suffered a great deal in writing his first essay entitled "Truth, Man and Choice" as he found it difficult to organise his ideas into a sequential order. After his initial contact with computers in 1960, he imagined a tool to help with conceptualisation. According to him, the whole problem was that a complicated idea did not lend itself easily to being reduced to linear form, suitable to being explained sequentially. It often appears to us as a tangled ball of wool that can be seen differently, depending on your point of view. What was needed then was a tool, which would record the links between the different facets of an idea, without obliging us to express them in a strictly linear manner. Nelson invented the neologism "structangle" to refer to the confused structure that the computer would be able to help us to clarify and use. In 1960, he promised himself that he would write his next book with the help of this tool. He thought that by 1962 it would all be ready. Twenty years later the programme had not been completed yet. In the following years this idea spawned the Xanadu project, which, to my knowledge, despite many assertions as to its completeness, is still unfinished.

However, since 1960, in the spirit of Theodor Nelson, the computer has opened up three new possibilities: 
1. Texts can be interconnected so that references to a specific author or a specific text can send the reader directly to the document cited, without any effort on his part.

2. Organisation, visualisation and comparison of ideas are now possible: the Xanadu project just mentioned is the result of this. It remains to describe and make the "structangles" referred to above.

3. The use of prefabricated constructions is also possible: as I understand it, Nelson is hoping to construct libraries of predefined structures which would help us to forge new ideas, by starting with fragments of old ideas, in order to compare ideas and to check on the originality of a supposedly new idea.

Of these three possibilities, only the first one has really seen the light of day. So, whilst Nelson's aspirations encompassed the organisation of ideas between themselves, only the interconnection of texts, otherwise called hypertext, has led to effective realisations

In 1965, five years after his first "illuminations", Nelson published in the proceedings of the twentieth national conference of the ACM (Association for Computing Machinery) an article entitled "A file Structure for the Complex, the Changing and the Indeterminate". In this, he described an original data structure intended to represent incomplete knowledge and to retrieve easily the corresponding information. On the technical level this data structure is built up with interconnected lists using symmetrical pointers. An appropriate language of manipulation preserves the structure of the texts across the interconnections, so that, for example, the order of notes reflects the order of the reference to the notes, even after a change on the source text. The links between the texts would thus indicate either a reference to a particular text or that one text had been copied in another.

Without going into detail we should note that Nelson was taking up the formalisms used by the pioneers of artificial intelligence, (Newell, Simon, Bachman, Bobrow and Weizenbaum amongst others) in order to create an external memory similar to the MEMEX conceived by Vannevar Bush. In addition to this computer specification, Theodor Nelson created another neologism in his 1965 article. He decided to call the interconnected text hypertext, because just as hyperspace extends and generalises space by adding a dimension to it, these interconnections extend text beyond the initial linearity of strings of characters. 
Finally, also in the same article, Theodor Nelson anticipated that, taking account of the drop in the price of computers ( $\$ 37,000$ in 1965), they would soon cost much less than a secretary. He thought that publishers, journalists or researchers should soon be taking advantage of them, which would justify using them as an aid to reading and writing.

\section{The heirs}

Many others followed the same path and gave substance to that which had been envisaged. I mention in particular Douglas Engelbart, who, at Stanford Research Institute in 1964 invented the mouse, as a controlled intermediary, facilitating the passage between our mental universe and the computer state. Douglas Engelbart also made a significant contribution to the development of hypertexts, seen as physical additions to ourselves with a view to increasing our intellectual capacities. It is worth noting in this context that with hypertext it is the boundary between our interior and exterior selves that tends to shift.

However, it was not until the eighties that hypertext became generally accessible on personal computers.

Then, during the nineties, hypertext itself was considerably extended by Tim Berners-Lee. He suggested moving beyond the individual computer to set up associative links with other computers through telecommunications networks, thus creating the principles of the "World Wide Web".

Independently of these technical developments, much thought was given to understanding hypertext and what distinguished it from traditional text. ${ }^{1}$

In the first place, hypertext breaks away to some extent from the linearity that we are accustomed to in traditional text. Of course, some dictionaries and encyclopaedias allow for non-linear access. Moreover, the network of indices and references present in biblical texts suggests other ways of reading. Finally, concise structures, such as aphorisms and poetry anthologies, do not require sustained reading. Nevertheless, until now, essays, novels, educational works were essentially intended for sequential and comprehensive reading. With

\footnotetext{
${ }^{1}$ See Jay D. BOLTER, Writing Space. The Computer, Hypertext and the History of Writing, Hillsdale New Jersey, Lawrence Erlbaum Associates Publishers 1991 and BOLTER, Jay David, "Literature in the Electronic Writing Space", in Literacy Online, The Promise (and Peril) of Reading and Writing with Computers, texts assembled by Myron C. TUMAN, University of Pittsburgh Press 1992, p. 19-42.
} 
hypertext, there is no longer any question about it; new narrative forms, such as branching novels, are envisaged.

Secondly, with the computer screen, the visual space can be configured as desired, according to requirements. The fixed space of the printed page is no longer a constraint. Various windows coexist, move relatively to one another, change shape and go with or against the stream of the text using a descending or ascending lift.

Thirdly, the links allow for a comparison between very different types of text. Starting with a single word, we call for an etymological dictionary, we consult for this same word occurring elsewhere in the text may or read a learned treaty.

These developments bring with them many consequences for both reading and writing.

Amongst these, the most important is that, as the author writes a new chapter, he does not know the reader's cognitive state because he does not know the exact order in which the chapters have been read. In short, there are numerous routes open to the reader who plays an increasingly active role, whereas the author is in part relinquishing power over the reader. He is no longer taking the reader by the hand, he is no longer the master, he just explains from time to time, depending on whether he is asked.

All these changes to the status of the reader, the author and the text inevitably bring to mind the theoretical writings of the so-called French neo-structuralists. And it is said in the United States, amongst those involved in hypertext studies, that hypertexts put into practice the theories of these philosophers, to the extent that makes reading them pointless. Regarding this, an American writer, Gregory L. Ulmer ${ }^{2}$ took a rhetorical construct, the play within a play, commented on at length by Jacques Derrida, and proceeded to deconstruct it, in the new and unpublished form of an electronic rhetoric. With the help of a hypermedia, containing various fragments of criticism and comments, and two processes described as editing and directing, an algorithm created texts by combining the initial fragments. The resulting machine generated analyses quite widely distributed in the hypertext community, expressed with the help of hypermedia, containing writings - or comments - from French neostructuralists, technical texts and newspaper articles. This theoretical

\footnotetext{
${ }^{2}$ Gregory ULMER, "Grammatology (in the Stacks) of Hypermedia, a Simulation: Or, when does a pile become a heap?" in Literacy Online, The Promise (and Peril) of Reading and Writing with Computers, texts assembled by Myron C. TUMAN, University of Pittsburgh press 1992, p. 139-158.
} 
trick makes a mockery of commonly held views. It can only spur us on to continue the analysis in order to try to measure more accurately the appropriateness of the writings of the French neo-structuralists to the theory of hypertexts.

\section{REFERENCE TO FRENCH “NEO-STRUCTURALISM”}

In order to do this we will go through the main commonly cited arguments that bring together the hypertext theoreticians and the French neo-structuralists. We will also look at original texts and the practical significance of the commonly cited arguments in the current context of the generalised use of hypertext.

\section{Beyond the printed page}

Let us begin with the most concrete aspect of texts, the printing on the page. In several of his works, Jacques Derrida freed himself from the constraints of traditional printing. To illustrate this here is the first page of $\mathrm{Glas}^{3}$, a work published in 1974 that places in parallel comments from Hegel's "Phenomenology of Spirit" and some of Jean Genet's literary writings.

\footnotetext{
${ }^{3}$ Jacques DERRIDA, Glas, Paris, Editions Galilée, collection Digraphe 1974
} 


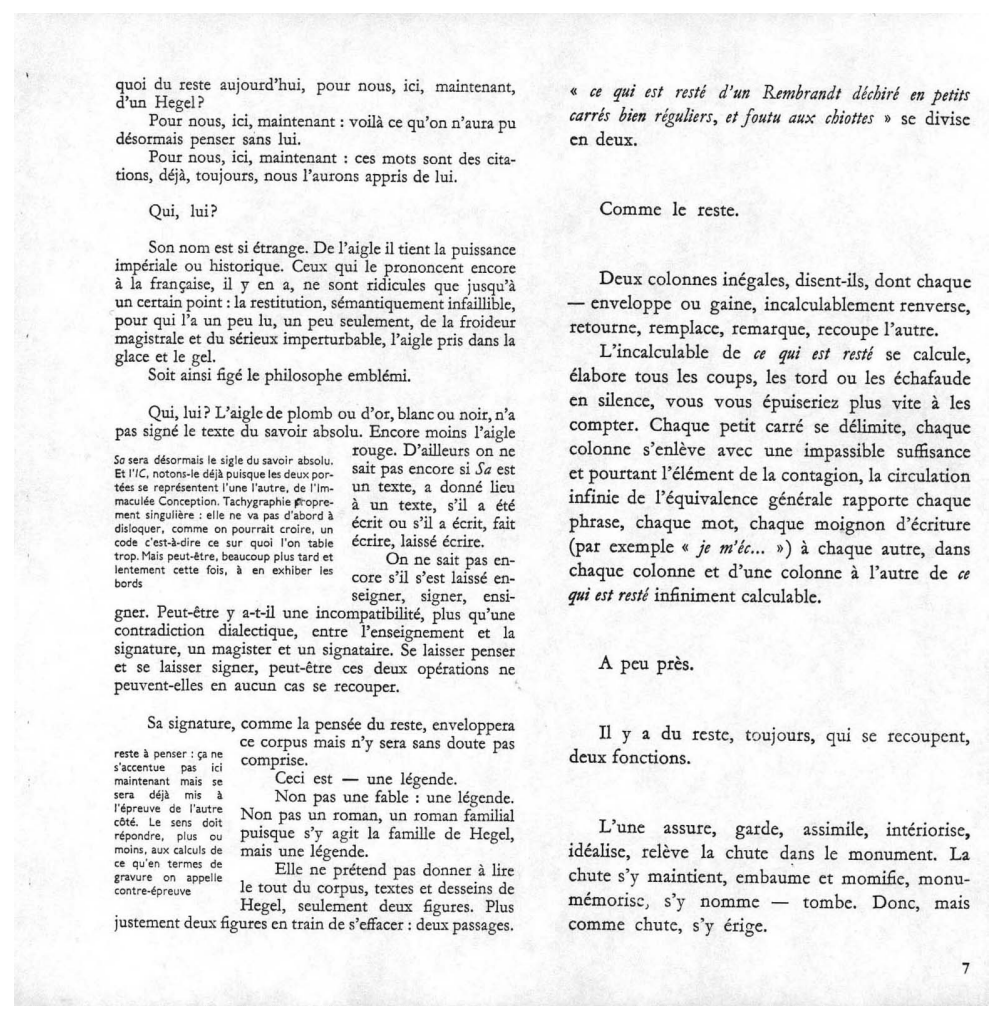

We are not considering here the text of this beautiful work, which blends speculative philosophy and literature. That alone would merit an extended and learned discussion. We will only examine its physical layout. First of all the square shape of the book breaks with convention. In addition, the size is clearly unusual. Then, the first page of the text begins with a letter in lower case, to suggest of course that this is a continuation of a text that has started elsewhere.

The page layout conveys the division between philosophy and literature: two columns are cut by comments, notes, glosses and definitions placed as inserts. Two different books to be read separately, but put in parallel each one distracts from the reading of the other. Added to these intertwined writings, is a mixture of different type sizes and fonts that ignore the rules of typography.

In fact, what we can see here a desire to free the visual space from the rules governing the printed page and to set out before the reader information of various kinds. What at first glance appears to resemble a hypermedia screen turns out to be very different. When looked at 
closely the aims seem to be altogether dissimilar. Hypertext offers the reader comments that appear on request to enhance reading or reply to questions. The fluidity of digitised text and the interconnections by means of symbolic links facilitate active communication from one text to another. Given this, the reader can follow the thread of his own curiosity, at his own pace. In Glas, Jacques Derrida infringes typographic rules and the conventions of page layout in order to decelerate reading, to slow down our movement over the space of the page and to force meditation, re-reading and contemplation of the texts. Is that his intention? Most certainly it is. A short passage from Dissemination testifies to his desire for the direction to be hidden.

A text is not a text unless it hides from the first comer, from the first glance, the law of its composition and the rules of its game. A text remains, moreover, forever imperceptible. Its law and its rules are not, however, harboured in the inaccessibility of a secret; it is simply that they can never be booked, in the present, into anything that could rigorously be called a perception.

Thus, perpetually and essentially, they risk being definitely lost. Who will ever know of such disappearances?

In any case, the dissimulation of the woven texture can take centuries to unravel its web. It is a web that envelops a web, unravelling its web for centuries. $^{4}$

In short, Derrida's stance opposes that of the originators of the hypermedia. On the one side, in Derrida's work we see a spatial layout designed according to what might be called "principle of dissimulation", whereas on the other side the hypertext theorists support an opposing principle, the "principle of transparency".

\section{Multiplicity of readings}

After examining physical layout, we now concentrate on the text itself and on reading. In his famous essay, S/Z, Roland Barthes divides the text of a Balzac short story, entitled Sarrasine, into 556 fragments called lexias. He explains his method clearly:

We shall therefore star the text, separating in the manner of a minor earthquake, the blocks of signification of which reading only grasps the smooth surface, imperceptibly soldered by the movement of sentences, the flowing discourse of narration, the naturalness of ordinary language. The

\footnotetext{
${ }^{4}$ Jacques DERRIDA, Dissemination, (trans. Barbara JOHNSON), Chicago University Press 1981, p.63
} 
tutor signifier will be cut up into a series of brief, contiguous fragments, which we shall call lexias, since they are units of reading. Admittedly, this cutting up will be arbitrary in the extreme; it will imply no methodological responsibility, since it will bear on the signifier, whereas the proposed analysis bears solely on the signified. ${ }^{5}$

Like so many stars floating away in a black sky, these lexias reassemble into constellations and give birth to different readings called codes. Roland Barthes' essay proposes five, but he hints at the existence of others still to be discovered.

Without going into the detail of Roland Barthes' very subtle analysis, we can observe a very clear structural analogy with hypertexts that take the reader on a number of journeys between fragments of text.

We should add here that Roland Barthes had a filing cabinet of readings in which he assembled notes and links in a way similar to that occurring in hypertext. As many people would encourage us to do, we could therefore find in Roland Barthes a pioneer and theoretician of "hypertextuality". However, a careful examination leaves a doubt.

Contrary to the precursors of hypertexts, who aspire to supply information, Roland Barthes considers the text to be already read. Besides, he only included it as an appendix to S/Z, and nothing encourages its reading. Far from proposing even a fragmentary reading of Balzac's text, Barthes leads us to multiple and unrelated readings of the text or more precisely of the letter of the text, otherwise expressed as "over readings", emphasising both their number and their irreverent character.

What we seek is to sketch the stereographic space of writing (which will here be a classic, readable writing). The commentary, based on the affirmation of the plural, cannot therefore work with "respect" to the text; the tutor text will ceaselessly be broken, interrupted without any regard for its natural divisions (syntactical, rhetorical, anecdotal); inventory, explanation, and digression may deter any observation of suspense, may even separate verb and complement, noun and attribute; the work of the commentary, once it is separated from any ideology of totality, consists precisely in manhandling the text, interrupting it. What is thereby denied is not the quality of the text (here incomparable) but its "naturalness."6

\footnotetext{
${ }^{5}$ Roland BARTHES, S/Z: An Essay (trans. Richard MILLER), Hill and Wang, N.Y. 1974, p.13

${ }^{6}$ Ibid. p. 15
} 
To sum up, on one side the hypertext encourages "under-reading" by giving easy access to units of information. These necessary markers separate the important aspects of the matter that would otherwise be drowned in an immense and monotonous ocean of text. On the other side, Roland Barthes' device encourages "over-reading", or in other words, further, deeper perusal of an ancient text, already well known but where further working would bear fruit, by bringing out new meaning.

Here, then we can see that the neo-structuralist system in no way legitimises theories of "hypertextuality", and in fact is just the opposite. "Over-reading", adding sense, bringing fresh material to ancient concepts, is contrary to "browsing" and picking up bits and pieces here and there in a text, unreadable through its sheer immensity.

\section{Death of the Author?}

"Over-reading", or more precisely the patient reconstruction which draws the reader into discovering the underlying structure of an old text, leads us to consider another oft-cited argument, not about the text but about the author, or rather his disappearance and the relationship between the author and reader.

In Vannevar Bush's writings, technical articles appear completely accessible and transparent. Hypertext gives easy access to them. The author retains a place as writer and text producer, but he effaces his individuality and provides only the content. From then on, the texts, the books and the author's body of work disappear to be replaced by a universal library to which all contribute. With his aptitude for flowery neologisms, Theodor Nelson gives the name "docuverse" to the universal, impersonal virtual library resulting from the interconnection of all the documents.

Among the French neo-structuralists, the loss of the author takes on quite a different significance. The author is not totally rejected into the impersonal obscurity of a contents manufacturer. In an address to the French Philosophical Society (Société Française de Philosophie) entitled "What is an Author?" Michel Foucault examines the conditions that define the existence of the author. Is it the total of his written output? If so, where does the body of his work stop? Do laundry lists or grocery orders of a great writer belong to his oeuvre? It is a current issue at a time when present techniques permit

\footnotetext{
${ }^{7}$ Michel FOUCAULT, "What is an Author?" Language, Counter-Memory, Practice: Selected Essays and Interviews, (trans. BOUCHARD \& SIMON), Cornell U.P.1977
} 
continual recording of our words and deeds at every moment of our lives.

Great literary figures of the past, authors of canonical religious texts or great scientists are unquestionably defined by their texts, books or their body of work, even if their own contribution, through these texts, books and bodies of work, does not belong wholly to them or relate only to one individual being, to a lone self.

However, Michel Foucault considers that since the 19th century, a new type of writer has appeared, not to be confused with the great authors of the past. They themselves are not reflected in their writings, or in their books or in their body of work, but in the break they have put in place in the minds. Freud and Marx are not only established authors of texts, but are authoritative references, or as Michel Foucault expresses it, they are "instigators of 'discursivity". After them works of literature are no longer read in the same way. In fact Foucault does not presage the death of the author, but his being strengthened, which is quite the reverse.

Here again the misunderstanding is clearly revealed. On the one hand, for the hypertext theoreticians the "self" of the author is obliterated in the impersonal and universal "docuverse". On the other hand, for Foucault and the other neo-structuralists, the death of the author, the distinction between writing, the text and its producer, all this establishes the figure of the "instigator of "discursivity". This is an author of a different kind, a "super-author", the master who guides ordinary writers and who himself defines the rules of the game. Moreover, everything bears out that this is a game, a gap, a vacant space to which, according to Jacques Derrida, all textual powers must be accorded:

If reading and writing are one, as is easily thought these days, if reading is writing, this oneness designates neither undifferentiated (con)fusion nor identity at perfect rest; the is that couples reading with writing must rip apart.

One must then, in a single gesture, but doubled, read and write. And that person would have understood nothing of the game who, at this [du coup], would feel himself authorized merely to add on; that is, to add any old thing. He would add nothing: the seam wouldn't hold. Reciprocally, he who through "methodological prudence," "norms of objectivity," or "safeguards of knowledge" would refrain from committing anything of himself, would not read at all. The same foolishness, the same sterility, obtains in the "not serious" as in the "serious." The reading or writing supplement must be rigorously prescribed, but by the necessities of a game, 
by the logic of play, signs to which the system of all textual powers must be accorded and attuned. ${ }^{8}$

\section{SHARED NIETZSCHEISM}

With the French neo-structuralists comes the breath of freedom. They invite us to re-read ancient works differently, freeing us from the weight of suffocating tradition. The perspective opened up by the hypertext theoreticians is proving to be quite different as it aims to extend man's cognitive limits. That being the case, how could such close ties have been woven between thinkers with such different concerns? I would like to present you with a hypothesis, which would necessitate lengthy justification. However, it would require more space than is here available to argue the case and more competence than I possess to do so.

I am presenting it, nevertheless, as it seems to me appropriate to open a polemic discussion. According to this working hypothesis, the proximity between the theoreticians of "hypertextuality" and the neostructuralists is not due to a synchronicity of concerns, but to what might be termed shared Nietzscheism, or more precisely, to having the same degree of sensitiveness to the themes presented in Nietzsche's work. Of course, in contrast to the neo-structuralists, for the hypertext theoreticians, this is partly, even completely, automatic as they do not refer explicitly to works of philosophy.

To substantiate this theory, I will simply take two very evident themes from Nietzsche's work, those of vitalism and superman, but obviously the theory could be applied to others.

\section{Vitalism}

Firstly, let us recall some elements of Nietzsche's theory of vitalism by quoting from "Untimely Meditations".

Is life to dominate knowledge and science, or is knowledge to dominate life? Which of these two forces is the higher and more decisive? There can be no doubt: life is the higher, the dominating force, for knowledge which annihilated life would have annihilated itself with it. Knowledge

\footnotetext{
${ }^{8}$ Jacques DERRIDA Dissemination, trans. Barbara JOHNSON Chicago University Press 1981, p.63
} 
presupposes life and thus has in the preservation of life the same interest as any creature has in its own continued existence. ${ }^{9}$

By careful scrutiny of the texts, we discover a vitalism among the neo-structuralists very similar to that of the theoreticians of "hypertextuality". Here are some examples.

Derrida's "Plato's Pharmacy", in the title itself, then in its contents and especially in the re-reading of the dialogue in Phaedrus, indicates evidence of such a concern. Let us remember that Derrida interprets the whole of Phaedrus which, as is well known, teaches the process of writing, as being a betrayal of speech and thence of truth, starting with the notion of the pharmakon, touched on in passing by Socrates at the start of the dialogue. Pharmakon refers to the poison and the remedy, a vehicle of death and a curative source. The Phaedrus, which seemed only to be a process of writing, now becomes the process of reproduction authorised by the writing, of identical repetition, and of replication seen as a kind of death. Just as the Pharmakon concerns both the remedy and the poison, so writing treats and revives thought while fixing it in a sterile form.

Similarly, in S/Z Roland Barthes deliberately chose "Sarrasine", a short story in which, from the first words, life confronts death:

Thus, on my right, the dark and silent image of death; on my left, the seemly bacchanalias of life: here cold nature, dull, in mourning; there, human beings enjoying themselves. On the borderline between these two so different scenes, which, a thousand times repeated in various guises, make Paris the world's most amusing and most philosophical city, I was making for myself a moral macédoine, half pleasant, half funereal. With my left foot I beat time, and I felt as though the other were in the grave. My leg was in fact chilled by one of those insidious drafts which freeze half our bodies while the other half feels the humid heat of rooms, an occurrence rather frequent at balls. ${ }^{10}$

In each case, by dint of "over-reading" the dead text an attempt is made to breathe life into it.

Vitalism is expressed by the hypertext theorists too, but in a slightly different fashion. It is clearly to be found in the work of Bush, in his desire to graft on to modern man an external memory, MEMEX. Theodor Nelson expresses it even more perfectly when he proposes the

\footnotetext{
${ }^{9}$ Friedrich NIETZSCHE, Untimely Meditations II On the Use and Abuse of History for Life, Breazeale, Hollingdale, Cambridge Texts in the History of Philosophy, p. 121

${ }^{10}$ Roland BARTHES, S/Z: An Essay (trans. Richard MILLER), Hill and Wang, N.Y. 1974, p.222
} 
hypothesis called "Gaia", taken from literature, which claims that the whole of human cultural heritage is said to behave like a living being maintaining its energy balance by bringing to its surface the elements required to cool and balance its calorific exchanges. Thus, according to Nelson, we find ourselves in a configuration similar to the Lovelock thesis according to which an algal bloom emerges on the surface of the ocean in order for energy to be lost and the ocean's temperature regulated.

Let us note in any case that of the two forms of vitalism discussed here, one aims to promote the inner nature of the singular reader by supplementing his intellectual life through the "reading-writing" approach to apparently dead texts. The second sets out to expand the life of each individual in an exterior world, this world being both physical, as shown precisely by Vannevar Bush's MEMEX, and spiritual, as expressed by Ted Nelson in his strange thermodynamic of cultural inflorescences. In conclusion, whilst vitalism for some is set on a conquest of the interior life, for others it aims to extend the power of life and the power of man over the outside world.

\section{The coming of the "superman"}

Another of Nietzsche's themes is that of the superman. We have seen how the neo-structuralists, in particular Michel Foucault, having declared the death of the author, substitute the instigator of discursivity, hailed, if not as a superman at least as a super-author, upsetting traditional interpretations so that classical works are reread in a new light; or, to go back to the words of Nietzsche himself, to organise interior chaos by reflecting on our real needs.

Similarly, Vannevar Bush, in seeking to extend the memory of the individual beyond its physiological limits, envisages a superior being, or superman. Equally, with the Xanadu project, Nelson is trying to stretch the capabilities of conceptualisation beyond their normal limits.

However, we see that here too misunderstanding persists. In their fidelity to Nietzsche's reasoning, the neo-structuralists wish to give back life and autonomy to the spiritual process submerged in the individual conscience by the overwhelming torrent of memory. They have to free themselves from the heavy weight of traditional authority and propose new ways of reading.

On the other hand, in the case of Vannevar Bush it is always a question of conquering the exterior world. Since the Second World War, this conquest has become a peaceful matter, it is no longer 
through the destruction of men but by their extensions beyond themselves, through the arrival of men newly grafted onto the exterior world and through new technical devices. There is no doubt that in consequence man will be different. If a man is seen as coupled to his prostheses, then he will be more powerful. We could then talk about "superman". However, having once been assisted, if he is then seen isolated and stripped of his instruments, he will once more become infirm and incapable of carrying out his normal tasks. We are certainly witnessing the coming of a new species, but an inferior species, a sort of "under-man".

We have been exploring the theories of "hypertextuality", current in the United States today. We have tried to understand several of the claims being made, in order to compare them with texts cited as examples in an attempt to assess their legitimacy. I believe that we have shown that there is a discrepancy between the two. In any case, we have not made any progress. We have not yet mastered the way of using these new techniques; we still understand poorly the cognitive processes of reading and writing and the changes brought about by the generalised concept of hypertext. Supporting arguments are mostly constructed from contemporary theories on "hypertextuality", not accounting for the real changes in ways of acquisition and conceptualisation. We should therefore form new theories, not based on pure speculation, but on a wealth of historical, psychological, and linguistic material. It is the only way to move our thinking forward on what is certainly one of the major issues of our age.

Jean-Gabriel GANASCIA

(CNRS-Pierre and Marie Curie University, Paris)

\section{REFERENCES}

BUSH, Vannevar "As We May Think", The Atlantic Monthly, July 1945. An electronic version of this text is available on the Web at the following address:

http:/www.isg.sfu.ca/ duchier/misc/vbush/

ENGELBART, Douglas C. "A Conceptual Framework for the Augmentation of Man's Intellect" in P. D. HOWERTON and D. C. WEEKS, Vistas in Information Handling, Washington, D.C., Spartan Books 1963, 1, p.1-29.

LYOTARD Jean-François, La Condition post-moderne, Paris, Les Editions de Minuit, collection "Critique" 1979. 
NELSON Theodor Holm, "A File Structure for The Complex, The Changing and Indeterminate", Association for Computing Machinery $20^{\text {th }}$ National Conference, 1965 p.84-100 in the conference proceedings. NELSON Theodor Holm, "Opening Hypertext: A memoir", in Literacy Online, The Promise (and Peril) of Reading and Writing with Computers, texts assembled by Myron C. TUMAN, University of Pittsburgh Press 1992, p. 43-57 